\title{
ACE inhibitors for heart failure: a question of dose
}

\author{
John G F Cleland, Philip A Poole-Wilson
}

Few treatments for cardiovascular disease have been shown to have such an impact on symptoms, morbidity, and mortality as have the angiotensin converting enzyme (ACE) inhibitors when used for the treatment of heart failure. A reduction in mortality has also been shown in patients treated with ACE inhibitors after myocardial infarction, particularly if heart failure or obvious ventricular dysfunction is present. The outcome of recent trials would be expected to lead to major changes in clinical practice, but, despite what seems overwhelming evidence of benefit, only a minority $(10-20 \%)$ of patients who stand to benefit currently receive an ACE inhibitor. ${ }^{1}$ The lack of impact on prescribing habits may indicate a reluctance on the part of physicians to change current practice or merely reflect a reasonable time delay as physicians learn the nuances of a new class of drug to be used in the clinical context of heart failure or myocardial infarction.

An additional concern is that up to $80 \%$ of patients who are receiving an ACE inhibitor are taking doses that are not known to be effective in reducing morbidity or mortality. ${ }^{2}$ Caution on the part of cardiovascular physicians has often been appropriate. Ten years ago thiazide diuretics were being used in doses 4-8 times higher than they are today and captopril was commonly used in doses in excess of $450 \mathrm{mg} /$ day. $^{3-5}$ Reductions in dose of both agents have led to a fall in the incidence of side effects. As a consequence of an understandable zeal to reduce doses to avoid side effects physicians may also be forfeiting benefit.

\section{ACE inhibition}

ACE inhibitors bind reversibly to ACE and dissociate from the enzyme as the plasma concentration of free drug falls. ${ }^{\circ}$ ACE inhibitors that have a high affinity for the enzyme dissociate slowly, and, although the plasma concentration of free drug may fall rapidly, the half life of the fraction bound to ACE can be very long. ${ }^{6}$ The drug may finally be eliminated only when ACE itself is degraded; in the case of tissue bound ACE this may take days. ACE is not the rate limiting enzyme for the formation of angiotensin II under normal circumstances, and about $80 \%$ of the activity of the enzyme must be inhibited before plasma concentrations of angiotensin II begin to fall. ${ }^{7}$ Detection of reduced formation of angiotensin II is a better marker of the efficacy of ACE inhibition than the degree of inhibition of the activity of the enzyme itself. If no free drug is present in the plasma to inhibit newly formed ACE, production of angiotensin II will resume. A higher dose of an ACE inhibitor, by maintaining the plasma concentration of unbound drug for longer, may not only inhibit the ACE more completely but also inhibit production of angiotensin II for longer. ${ }^{6}$

\section{Theoretical arguments for using low doses}

Although substantial doses of ACE inhibitors are required to suppress the formation of angiotensin II for more than a few hours, some investigators suggest that high doses of ACE inhibitors are not necessary to exert clinical benefit. Preliminary studies have suggested that small doses of an ACE inhibitor-for example, captopril $1 \mathrm{mg}$-can enhance renal salt and water excretion without altering circulating neuroendocrine factors or haemodynamics. ${ }^{8}$ Animal data suggest that small doses of ramipril can prevent ventricular hypertrophy without reducing blood pressure, a potentially dangerous effect. ${ }^{9}$ These data await confirmation but suggest that inhibition of circulating ACE to reduce plasma angiotensin II may not be a necessary or important action of ACE inhibitors.

Many, though not all, investigators believe that the haemodynamic effects of ACE inhibitors are poorly related to the activity of the plasma renin-angiotensin system. ${ }^{10}{ }^{11}$ There are several explanations for these observations. Tissue ACE may be more sensitive to the effects of ACE inhibitors, or their effects in tissues may persist for longer. ${ }^{12}{ }^{13}$ Tissue ACE is found mainly on the luminal surface of the vascular endothelium ${ }^{14}$ and is the main source of plasma ACE. ACE inhibitors bound to tissue and plasma ACE are probably in a dynamic equilibrium during long term treatment. Alternative metabolic pathways for the conversion of angiotensin I to II by chymases, ${ }^{12}$ changes in electrolyte homoeostasis, altered tone of the vascular smooth muscle cell, changes in plasma volume, secondary effects on the bradykininprostaglandin system, and long term structural changes in the arterial wall itself are options to explain the dissociation of the haemodynamic effects of ACE inhibition from plasma reninangiotensin system activity. Only small doses of an ACE inhibitor may be required to reduce the degradation of bradykinin, which may be an important mediator of ACE inhibitor action. $^{12}$

Brief periods of suppression of angiotensin II have been argued to be preferable to prolonged inhibition. Allowing angiotensin II 
to rise periodically might ameliorate the decline in glomerular filtration rate observed with ACE inhibitors in heart failure, by allowing blood pressure and efferent arteriolar tone to rise at regular intervals. ${ }^{15}$ High doses of long acting ACE inhibitors result in a greater decline in glomerular filtration rate, but the effect is generally small. On balance, however, long acting ACE inhibitors have an equal or greater benefit on clinical symptoms so long as the decline in renal function is not prominent. ${ }^{16}$

During long term ACE inhibition in patients with hypertension, ${ }^{17}$ after myocardial infarction, ${ }^{18}$ or with heart failure ${ }^{19}$ enalapril up to $10 \mathrm{mg}$ twice daily or ramipril $10 \mathrm{mg}$ once daily have failed to reduce plasma angiotensin II concentrations. These data need to be confirmed by others as the assay for angiotensin II is prone to technical problems, especially cross reactivity with angiotensin I, concentrations being greatly raised during long term ACE inhibition. ${ }^{20}$ Lower doses of ACE inhibitors could be more effective in lowering angiotensin II concentrations long term, as described below.

Reduction in angiotensin II concentration leads to a loss of feedback inhibition on renin secretion and to upregulation of angiotensin II receptors. ${ }^{21}$ Long term ACE inhibition leads to hypertrophy of the juxtaglomerular apparatus and increases in plasma concentrations of active renin of up to 100 -fold. ${ }^{22}$ Increases in renin concentration lead to increased conversion of angiotensinogen to angiotensin I. ${ }^{23} 24$ The accumulation of angiotensin I then competes with the ACE inhibitor for binding to the enzyme, leading to renewed formation of angiotensin II. Angiotensin I may also be converted to angiotensin II by enzymes other than ACE such as cardiac chymase. ${ }^{11}$ Periodic loss of effective ACE inhibition could prevent an excessive rise in renin concentration, accumulation of angiotensin I, and upregulation of angiotensin II receptors, thereby preserving the ability of ACE inhibitors to suppress effectively angiotensin II long term.

The argument is speculative. Evidence that alternative pathways of conversion of angiotensin I to angiotensin II are clinically relevant in humans is not available, and less reactive hyperreninaemia may merely reflect less effective suppression of angiotensin II formation.

\section{Theoretical arguments for using high doses}

Prevention of the formation of angiotensin II is believed to be the fundamental mechanism of action of ACE inhibitors by many investigators. On starting treatment with an ACE inhibitor small doses-for example, captopril $6.25 \mathrm{mg}$ - can completely inhibit the formation of angiotensin II for brief periods (10-15 minutes) in patients with heart failure. ${ }^{25}$ During long term ACE inhibition plasma concentrations of active renin rise up to 100-fold, resulting in a greatly increased capacity to synthesise angiotensin I, which competes with the inhibitor for binding to the enzyme. ${ }^{22} 26$ Moderately large doses of ACE inhibitors can suppress, long term, the formation of angiotensin II in heart failure partially, ${ }^{26}{ }^{27}$ while doses of enalapril at $40 \mathrm{mg} /$ day can suppress angiotensin II more or less completely throughout 24 hours. $^{22}$ Small increases in ACE activity, through partial loss of ACE inhibition, will lead to the rapid rise in plasma angiotensin II concentration. Doses of an ACE inhibitor that adequately suppress angiotensin II formation throughout the day initially, may fail to do so during long term treatment. Additionally, during long term ACE inhibition angiotensin II receptor upregulation may result in smaller plasma concentrations of angiotensin II having more profound effects on vascular tone or aldosterone secretion. This may explain why, after an initial fall, aldosterone concentrations tend to rise during long term ACE inhibition, though adrenal stimulation secondary to an increase in potassium concentration is an alternative explanation.

Complete suppression of angiotensin II throughout the 24 hours may be important in obtaining not only the greatest haemodynamic benefit but also the most benefit from the prevention of the direct effects of angiotensin II on tissues and the sympathetic nervous system. $^{25}$ More profound ACE inhibition results in a greater rise not only in serum creatinine concentration but also in potassium concentration. ${ }^{15}$ Hyperkalaemia may be important in preventing arrhythmias and improving skeletal and cardiac muscle function. Intense ACE inhibition during long term treatment also enhances a frusemide induced diuresis. ${ }^{28}$

The doses of ACE inhibitors used in clinical studies so far may not completely suppress angiotensin II over 24 hours. ${ }^{17-19} 26$ Higher doses of ACE inhibitors than used heretofore might produce even greater benefit. Even larger doses of ACE inhibitors than those required to suppress angiotensin II may be required for optimal effects on bradykininprostaglandin mediated effects or other as yet poorly described effects of ACE inhibitors on other systems, such as erythropoietin, substance $P$, nitric oxide, and vasoactive intestinal polypeptide. Animal studies have shown that high doses of ACE inhibitors (human dose equivalent of $3000 \mathrm{mg} /$ day of captopril) can retard the development of atherosclerosis. ${ }^{29}$ Such large doses would not be tolerated by many patients, but the upper end of the therapeutic dose-response relation with ACE inhibitors has not been fully explored.

\section{Clinical evidence for the effectiveness of high doses}

Most of the major studies on the effect of ACE inhibitors on symptoms and all the major studies of the effects on prognosis have used high doses of ACE inhibitors. ${ }^{30-34}$ Moreover, ACE inhibitors have usually been given more frequently than is common clinical practice. Enalapril $10 \mathrm{mg}$ twice daily is a more effective 
antihypertensive regimen than $20 \mathrm{mg}$ once daily, probably because it suppresses production of angiotensin II over 24 hours more effectively. ${ }^{35}{ }^{36}$ Captopril $25 \mathrm{mg}$ thrice daily probably does not inhibit angiotensin II production effectively over 24 hours in patients with heart failure during long term dosing, though $50 \mathrm{mg}$ thrice daily may do so. ${ }^{26}$

The early studies that conclusively showed the benefits of ACE inhibitors on symptoms and exercise performance used fairly high doses-for example, captopril 50-100 mg thrice daily and enalapril $40 \mathrm{mg}$. ${ }^{22} 2637 \mathrm{High}$ doses in these studies were generally well tolerated, and about $80 \%$ of patients took full doses.

The target dose of enalapril in the original CONSENSUS study was $20 \mathrm{mg}$ twice daily. ${ }^{30}$ Despite the fact that the patients in this study had severe heart failure and were receiving high doses of diuretics, $22 \%$ achieved the top dose. More patients would probably have tolerated this dose if the investigators had applied the study protocol more rigorously; only $45 \%$ of patients randomly allocated to placebo achieved the target "dose," indicating a reluctance on the part of the investigators even to try high doses. Nevertheless, the mean daily dose was $18.4 \mathrm{mg} /$ day - that is, about 9.2 $\mathrm{mg}$ twice daily - and this was associated with a $50 \%$ reduction in mortality in patients with heart failure due to ischaemic heart disease. ${ }^{38}$ The table shows the mean dose of ACE inhibitor in the other major studies. In these landmark trials ACE inhibitors, used in high doses, were able not only to reduce mortality but also to prevent progressive ventricular dysfunction.

\section{Clinical evidence for the effectiveness of low doses}

Properly designed clinical trials showing clinical benefit with low doses of ACE inhibitors are few. Brilla et al found an improvement in symptoms in a single blind placebo controlled trial of enalapril $5 \mathrm{mg}$ once daily. ${ }^{39}$ Two small double blind studies of enalapril in doses of $5 \mathrm{mg}$ twice daily have also shown beneficial effects on symptoms and exercise performance. ${ }^{4041}$ The study by Kleber et al in 170 patients with mild heart failure is the only placebo controlled trial that shows an improvement in a combined morbiditymortality end point with a fairly low dose of an ACE inhibitor (captopril $25 \mathrm{mg}$ twice daily) ${ }^{42}$

Several clinical trials of ACE inhibitors after myocardial infarction show that doses of captopril as low as $75-100 \mathrm{mg} /$ day modify ventricular remodelling. ${ }^{44}$ Thus, doses of captopril one half that targeted in the SAVE study are associated with some clinical evidence of benefit.

\section{Clinical comparisons of high and low dose ACE inhibition}

No adequate comparisons of the symptomatic or prognostic benefits of low versus high doses of ACE inhibitors yet exist.

Riegger found a dose-response relation with quinapril in doses ranging from $5 \mathrm{mg}$ to $20 \mathrm{mg}$ twice daily, patients receiving higher doses having greater increments in exercise performance. ${ }^{45}$ However, during a subsequent one year open label follow up study the most popular choice of quinapril dose was the lowest, with $71 \%$ of patients taking $5 \mathrm{mg}$ twice daily. These data need to be substantiated in further clinical trials.

Pacher et al in a non-randomised comparison of more than or less than $25 \mathrm{mg}$ captopril thrice daily found that patients taking higher doses were less likely to undergo transplantation or die. ${ }^{46}$ Patients taking the higher dose were also more likely to have a reduction in plasma concentrations of aldosterone and atrial natriuretic peptide. As the study was not randomised the sicker patients may have tolerated high doses of captopril less well. Thus the ability to tolerate high doses of captopril may indicate an intrinsically better prognosis. Also, transplantation is not a satisfactory trial end point because the indications for referral and the criteria for acceptance on to a waiting list vary. Factors

Relative efficiency in terms of lives saved per month's treatment in trials of ACE inhibitors

\begin{tabular}{|c|c|c|c|c|c|c|c|}
\hline \multirow[t]{2}{*}{ Trial } & \multirow[t]{2}{*}{ Agent } & \multirow[t]{2}{*}{ Frequency } & \multirow{2}{*}{$\begin{array}{l}\text { Total daily dose of } A C E \\
\text { inhibitor (target/achieved) }\end{array}$} & \multirow[t]{2}{*}{ Comparator } & \multirow{2}{*}{$\begin{array}{l}\text { Mean duration } \\
\text { of trial (months) }\end{array}$} & \multicolumn{2}{|l|}{ Survival } \\
\hline & & & & & & Absolute benefit ${ }^{\star}$ & $\begin{array}{l}\text { Relative benefit } \\
(\% \text { risk reduction) }\end{array}$ \\
\hline CONSENSUS & Enalapril & Twice daily & $40 \mathrm{mg} / 18.4 \mathrm{mg}$ & Placebo & $6 \cdot 3$ & $22 \cdot 9$ & 27 \\
\hline $\begin{array}{l}\text { V-HeFT II } \\
\text { SOLVD: }\end{array}$ & Enalapril & Twice daily & $20 \mathrm{mg} / 15 \mathrm{mg}$ & Hydralazine-nitrate & 30 & $1 \cdot 8$ & 11 \\
\hline Treatment & Enalapril & Twice daily & $20 \mathrm{mg} / 16.6 \mathrm{mg}$ & Placebo & $41 \cdot 4$ & $1 \cdot 1$ & 16 \\
\hline Prevention & Enalapril & Twice daily & $20 \mathrm{mg} / 16.7 \mathrm{mg}$ & Placebo & $37 \cdot 4$ & $0 \cdot 3$ & 8 \\
\hline SAVE & Captopril & Thrice daily & $150 \mathrm{mg}(79 \%$ achieved target $)$ & Placebo & 42 & $1 \cdot 0$ & 19 \\
\hline AIRE & Ramipril & Twice daily & $10 \mathrm{mg}(77 \%$ achieved target $)$ & Placebo & 15 & $3 \cdot 5$ & 27 \\
\hline ISIS-4 & Captopril & Twice daily & $\begin{array}{l}100 \mathrm{mg}(83 \% \text { on active } \\
\text { treatment at end })\end{array}$ & Placebo & 1 & $4 \cdot 6$ & 7 \\
\hline GISSI-3 & Lisinopril & Once daily & $10 \mathrm{mg}$ (data awaited) & Placebo & $1 \cdot 5$ & $5 \cdot 3$ & 12 \\
\hline ISIS-2† & Streptokinase & - & Not applicable & Placebo & $1 \cdot 2$ & $22 \cdot 2 \ddagger$ & 25 \\
\hline $\begin{array}{l}\text { MRC trial of mild } \\
\text { hypertensiont }\end{array}$ & $\begin{array}{l}\text { Thiazide or } \\
\text { propranolol }\end{array}$ & - & Not applicable & Placebo & 66 & $\begin{array}{l}\text { Death } 0.0049 \\
\text { Stroke } 0.048\end{array}$ & 45 \\
\hline
\end{tabular}

*No of lives saved (all cause) during one month's treatment of 1000 patients.

tGiven as comparator.

tVascular deaths only.

These data should be interpreted with caution, however. Although the effect of one month's treatment in some of the postinfarction trials is striking, this may reflect a short term benefit during a period of high risk; little greater benefit may be had by longer term treatment in patients without marked ventricular dysfunction. In other words, the apparent absolute benefit per month of treatment will diminish with longer term treatment. Nevertheless, these data provide proof that to treat all patients with high doses of ACE inhibitors after infarction is one inexpensive method of saving lives. The studies do not provide conclusive evidence that high dose treatment of all patients is optimal or the least expensive clinical practice. 
other than the severity of heart failure, such as blood group, may influence which patients undergo transplantation.

Pouleur et al reported a retrospective analysis of a trial of xamoterol in severe heart failure. ${ }^{47}$ The abrupt introduction of xamoterol increased mortality, but patients taking captopril had a higher mortality than those taking enalapril. The authors suggested that the long acting ACE inhibitor had superior prognostic benefits to the shorter acting one. It is difficult to judge whether the dose of enalapril and captopril were equivalent. An alternative explanation is that the dose of captopril was effectively lower than the dose of enalapril and that no difference would have been observed had equipotent doses been used. Any ACE inhibitor, including captopril, will induce 24 hour suppression of angiotensin II concentrations if given in large enough doses, at least in the short and medium term.

The only randomised dose ranging study so far purporting to investigate morbidity in heart failure included only 27 patients, but the results showed that patients taking enalapril $15 \mathrm{mg}$ twice daily were less likely to deteriorate than patients taking $2.5 \mathrm{mg}$ twice daily. ${ }^{48}$

\section{Practical issues}

The major goals of treating severe heart failure are to ameliorate symptoms, improve quality of life, and reduce mortality. In severe heart failure the prognosis is poor even in patients treated with ACE inhibitors and a reduction in mortality alone may be a critical end point only in exceptional groups of patients such as those awaiting transplantation. On the other hand, in frail elderly patients prognosis may not be an issue at all. In these circumstances use of the smallest dose that adequately relieves symptoms but minimises side effects is justified. Several properly controlled studies have shown that ACE inhibitors are effective in improving symptoms and exercise performance when given at low doses and that only a minority need to be titrated to higher doses to improve clinical status. ${ }^{49} 50$ Alternatively, if symptoms are already well controlled, prognosis is the principal reason for treating a patient with an ACE inhibitor. Since myocardial infarction and progression of heart failure may be irreversible and death certainly so, physicians, on current evidence, should titrate up to the dose used in the large clinical trials when treating to delay worsening heart failure or death.

There are a few exceptions to this last statement. Most ACE inhibitors are excreted by the kidney, and even at small doses they may have a protracted effect if the glomerular filtration rate is low. Patients with renal dysfunction may not require high doses. All elderly patients with heart failure have renal dysfunction. The large clinical trials have enrolled few patients over 70, yet this group constitutes most patients with heart failure. The optimal dose of ACE inhibitor to improve prognosis in elderly patients is not known, although titration of the dose against symptoms may be optimal management in many. Dose will need to be adjusted according to the patient's size and body type.

\section{Studies under way}

Two large trials have been initiated to determine whether high doses of ACE inhibitors are superior to lower doses. The NETWORK study, due to complete in 1994, will randomly allocate 1500 patients to enalapril $2.5 \mathrm{mg}, 5 \mathrm{mg}$, or $10 \mathrm{mg}$ twice daily for six months. The primary end point is the combined end point of death, admission to hospital for heart failure, and worsening heart failure. The study is designed to detect a difference between the highest and lowest dose, with the middle dose occupying an intermediate position. The ATLAS study has the primary end point of all cause mortality. This study will randomly allocate 3000 patients to receive lisinopril either at low dose $(2.5 \mathrm{mg}$ or $5 \mathrm{mg}$ once daily, according to local practice) or at high dose (32.5 mg or $35 \mathrm{mg}$ once daily); the expected minimum follow up time is two years, recruitment has been completed this year, and reporting is expected in 1996. A further study (ACHIEVE) will also consider the dose of quinapril in relation to the cost effectiveness of ACE inhibitor treatment. These studies should add significantly to our current knowledge of how to treat heart failure.

1 McMurray J, Hart W, Rhodes G. An evaluation of the cost of heart failure to the National Health Service in the UK. British fournal of Medical Economics 1993;6:99-110.

2 Food and Drugs Administration. Data on file, March 1992. Washington, DC: FDA, 1992

3 Medical Research Council Working Party. MRC trial of treatment of mild hypertension: principal results. $B M \mathcal{J}$ 1985;291:97-104.

4 MacGregor GA, Markandu ND, Roulston JE, Jones JC. Essential hypertension: effects of an oral inhibitor of angiotensin-converting enzyme. BMF 1979;ii:1106-9.

5 Davis R, Ribner HS, Keung E, Sonnenblick EH, LeJemtel TH. Treatment of chronic congestive heart failure with captopril, an oral inhibitor of angiotensin-converting enzyme. $N$ Engl f Med 1979;301:117-21.

6 Elliott HL, Macdonald NJ, Meredith PA, Reid JL. Dose responses and pharmacokinetics for the angiotensin responses and pharmacokinetics for the angiotensin
Ther 1992;51:260-5.

7 de Leeuw PW, Hoogma RPLM, van Soest GAW, Tchang PT, Birkenhager WH. Humoral and renal effects of MKPT, Birkenhager WH. Humoral and renal effects of MK421 (enalapril) in hyper

8 Motwani JG, Fenwick MK, Morton JJ, Struthers AD. Furosemide-induced natriuresis is augmented by ultralow-dose captopril but not by standard doses of captopril in chronic heart failure. Circulation 1992;86:439-45.

9 Linz W, Scholkens BA, Ganten D. Converting enzyme inhibition specifically prevents the development and induces the regression of cardiac hypertrophy in rats. Clin Exp Hypertens [A] 1989;11:1325-50.

10 Dzau VJ. Molecular and physiological aspects of tissue renin-angiotensin system: emphasis on cardiovascular control. $\mathcal{F}$ Hypertens 1988;6:S7-12.

11 Packer M, Medina N, Yushak M, Lee WH. Usefulness of plasma renin activity in predicting haemodynamic and clinical responses and survival during long-term converting enzyme inhibition in severe chronic hear failure: experience in 100 consecutive patients. $\mathrm{Br}$ Heart f 1985;54:298-304.

12 Morgan $\mathrm{K}$. Diverse factors influencing angiotensin metabolism during ACE inhibition: insights from molecular biology and genetic studies. Br Heart $\mathcal{f} 1994$ 72(3)(suppl):S3-10.

13 MacFadyen RJ, Lees KR, Reid JL. Tissue and plasma angiotensin converting enzyme and the response to $\mathrm{ACE}$ inhibitor drugs. Br 7 Clin Pharmacol 1991;31:1-13.

14 Caldwell PRB, Seegal BC, Hsu KC, Das M, Soffer RL. Angiotensin-converting enzyme: vascu
localisation. Science 1976;191:1050-1. 
15 Packer M, Wai-Hung-Lee, Yushak M, Medina N. Comparison of captopril and enalapril in patients with severe
chronic heart failure. $N$ Engl $\mathscr{Y}$ Med 1986;315:847-53.

16 Giles RD, Katz R, Sullivan JM, et al. Short and long-acting angiotensin-converting enzyme inhibitors: a randomised angiotensin-converting enzyme inhibitors: a randomised
trial of lisinopril versus captopril in the treatment of trial of lisinopril versus captopril in the treatment of congestive

17 Weber MA, Neutel JM, Smith DH. Circulatory and extracirculatory effects of angiotensin-converting enzyme inhibition. Am Heart f 1992;123:1414-20.

18 Sigurdsson A, Held P, Swedberg K, Wall B. Neurohormonal effects of early treatment with enalapril after acute myocardial infarction and the impact on left ventricular remodelling. Eur Heart f 1993;14:11 10-7.

9 Sigurdsson A, Swedberg K, Ullman B. Effects of ramipril on the neurohormonal response to exercise in patients with mild or moderate congestive heart failure. Eur Hear f 1994;15:247-54.

20 Atkinson AB, Morton JJ, Brown JJ, et al. Captopril in clinical hypertension: changes in components of reninangiotensin systems and in body composition in relation to fall in blood pressure, with a note on measurement of to fall in blo Heart $\mathcal{f} 1980 ; 44: 290-6$.

21 Cody RJ, Covit AB, Schaer GL, Laragh JH. Estimation of angiotensin II receptor activity in chronic congestive angiotensin II receptor activity in chroni

22 Cleland JGF, Dargie HJ, Ball SG, et al. Effects of enalapril in heart failure: a double blind study of effects on exercise performance, renal function, hormones, and metabolic state. Br Heart $\mathcal{f} 1985 ; 54: 305-12$.

23 Atkinson $\mathrm{AB}$, Cumming AMM, Brown JJ, et al. Captopril treatment: inter-dose variations in renin, angiotensins and II, aldosterone, and blood pressure. $\mathrm{Br} f \mathrm{Clin}$ Pharmacol 1982;13:855-8.

24 Mooser V, Nussberger J, Juillerat L, et al. Reactive hyperreninemia is a major determinant of plasma angiotensin II during ACE inhibition. 7 Cardiovasc Pharmacol 1990 15:276-82.

25 Cleland J, Semple P, Hodsman P, Ball S, Ford I, Dargie H. Angiotensin II levels, hemodynamics and sympathoadrenal function after low-dose captopril in heart failure. Am $\mathcal{F}$ Med 1984;77:880-6.

26 Cleland JGF, Dargie HJ, Hodsman GP, et al. Captopril in heart failure: a double blind controlled trial. Br Heart $f$ 1984;52:530-5.

27 Cleland JGF, Shah D, Krikler S, et al. The effects of lisinopril on cardiorespiratory, neuroendocrine, and renal function in patients with asymptomatic left ventricular function in patients with asymptomatic

28 Good J, Brady A, Meek J, Oakley C, Cleland J. Intense inhibition of angiotensin converting enzyme (ACE) en-
hances frusemide induced diuresis during chronic ACE hances frusemide induced diuresis during chronic ACE
inhibitor therapy [abstract]. Br Heart 7 1992; inhibitor ther

29 Chobanian AV, Haudenshild CC, Nickersson C, Drago R Antiatherogenic effects of captopril in the Watanabe heritable hyperlipidaemic rabbit. $\mathcal{f}$ Hypertens 1990 15:327-31.

30 CONSENSUS Trial Study Group. Effects of enalapril on mortality in severe congestive heart failure. Results of the cooperative North Scandinavian enalapril survival study (CONSENSUS). $N$ Engl f Med 1987;316:1429-35.

31 Cohn JN, Johnson G, Ziesche S, et al. A comparison of enalapril with hydralazine-isosorbide dinitrate in the treatment of chronic congestive heart failure. $N$ Engl f Med 1991;325:303-10.

32 Yusuf S, Pepine CJ, Garces C, et al. Effect of enalapril on myocardial infarction and unstable angina in patients with low ejection fractions. Lancet 1992;340:1173-8.

33 Pfeffer M, Braunwald E, Moye LA, et al. Effect of captopril on mortality and morbidity in patients with left ventricular dysfunction after myocardial infarction. $N$ Engl f Med 1992;327:669-77.

34 Acute Infarction Ramipril Efficacy (AIRE) Investigators. Effect of ramipril on mortality and morbidity of survivors Effect of ramipril on mortality and morbidity of survivors heart failure. Lancet 1993;342:821-8.

35 Meredith PA, Donnelly R, Elliott HL, et al. Prediction of the anti-hypertensive response to enalapril. $\mathcal{F}$ Hyperten 1990;8:1085-90.

36 Biollaz J, Schelling JL, Jacot des Combes B, et al. Enalapril maleate and a lysine analogue (MK521) in normal volunteers: relationship between plasma drug levels and the renin-angiotensin system. $\mathrm{Br} \quad \mathcal{F}$ Clin Pharmacol 1982;14:363-8.

37 Captopril Multi-Center Research Group. A placebo-controlled trial of captopril in refractory chronic congestive heart failure. $f \mathrm{Am}$ Coll Cardiol 1983;2:755-63.

38 Nony P, Boissel JP, Girard P, Leizorovicz A, Lievre M, Chifflet R. Relative efficacy of angiotensin converting enzyme inhibitors on mortality of patients with congestive heart failure: implications of randomised trials and role of the aetiology (ischaemic or non-ischaemic) of heart failure. Eur Heart f 1992;13:1101-8.

39 Brilla CG, Kramer B, Hoffmesietr HM, MullerSchauenburg W, Risler T, Sepel L. Low-dose enalapril in Schauenburg W, Risler T, Sepel L. Low-dose enalapril in Therapy 1989;3:211-8.

40 Sharpe DN, Murphy J, Coxon R, Hannan SF. Enalapril in patients with chronic heart failure: a placebo-controlled, randomized, double-blind study. Circulation 1984, 70:271-8.

41 Franciosa JA, Wilen MM, Jordan RA. Effects of enalapril a new angiotensin converting enzyme inhibitor, in controlled trial in heart failure. $\mathcal{F} A C C$ 1985;5:101-7.

42 Kleber FX, Niemoller L, Doering W. Impact of convertin enzyme inhibition on progression of chronic heart failure: results of the Munich mild heart failure trial. Br Heart $f$ 1992;67:289-96

43 Sharpe N, Smith H, Murphy J, Greaves S, Hart H, Gamble G. Early prevention of left ventricular dysfunction following myocardial infarction. Lancet 1991;i:872-4.

44 Ray SG, Pye M, Oldroyd KG, et al. Captopril after acute myocardial infarction. Br Heart $\mathcal{f}$ 1993;69:215-22.

45 Riegger GAJ. Effects of quinapril on exercise tolerance in patients with mild to moderate heart failure. Eur Heart 7 patients with mild

46 Pacher R, Globtis S, Bergler-Klein J, et al. Clinical and neurohumoral response of patients with severe congestive neurohumoral response of patients with severe congestive Eur Heart 7 1993;14:273-8.

47 Pouleur H, Rousseau MF, Oakley CM, Ryden I Difference in mortality between patients treated with captopril or enalapril in the xamoterol in severe hear failure study. Am $\mathcal{f}$ Cardiol 1991;68:71-4.

48 Vagelos R, Nejedly $M$, Willson K, Gail Yee Y, Fowler $M$ Comparison of low versus high dose enalapril therapy for patients with severe congestive heart failure [abstract]. $\mathscr{f}$ Am Coll Cardiol 1991;17(suppl):275A.

49 Lewis GR. Comparison of lisinopril versus placebo for congestive heart failure. Am 7 Cardiol 1989;63:12-6D.

50 Dossegger $L$, Aldor E, Baird MG, et al Influence angiotensin converting enzyme inhibition on exercise performance and clinical symptoms in chronic heart failure: a multicentre, double-blind placebo-controlled trial. Eur Heart $\mathcal{f} 1993 ; 14$ (suppl C): 18-23. 